DANIELA TOŠEVA

UDC: 801.6

Institute of Classical Studies

Ss. Cyril and Methodius University

Skopje

\title{
THE 'MELOS' OF THE DITHYRAMB
}

\begin{abstract}
In the present paper I discuss the generic identity of dithyrambic poetry starting with the famous Archilochus' fr. 120 West. My approach to the subject in the first section is analytical, in which I examine the key words of the Archilochus fragment related to the chorus and choral performance in order to establish a basis for the second part of the discussion. I also comment on the early poets, who wrote dithyrambs in order to confirm the ritual and religious aspects of the early dithyramb. The second section is concerned with the generic identity of the dithyramb viewed from a formalistic aspect; in this section I am investigating Pindar and Bacchylides' dithyrambs. They composed lyric poetry at the beginning of the 5th century BC, when tragedy became the most popular form of performance in Athens. The approach is systematic, dealing with the performances and the performers of dithyrambs, as well as with the text of the dithyrambs as a primary source. This attempt will demonstrate conclusively which part of the dithyrambic melos (a composition of song, dance and musical accompaniment) is the most stable feature of the genre.
\end{abstract}

\section{On the Origins of the Dithyramb}

\subsection{Archilochus' Dithyramb}

The word dithyramb was first attested in the iambic poet Archilochus $\left(7^{\text {th }}\right.$ century BC), ${ }^{1}$ where it was denoted as $\mu \varepsilon^{\prime} \lambda$ o $\varsigma$ ("song") sung

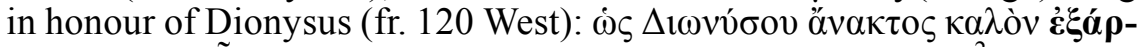

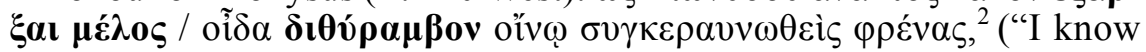

${ }^{1}$ The dithyramb was ignored in the Homeric poems, just as the god Dionysus was avoided, even though it was attested that his worship went back to the Bronze Age.

${ }^{2}$ This fragment is cited in Athenaeus (Deipn. 628a) as an example of the distinction between (1) the celebration of Dionysus with the turbulent dithyramb and (2) the celebration of Apollo with the more tranquil paean:

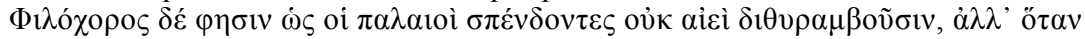

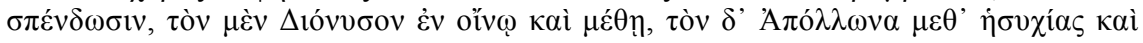

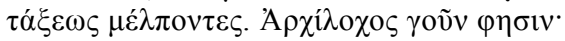

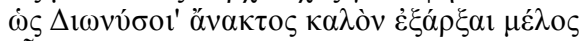

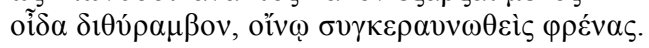

"Philochorus says that when the ancients poured libations they did not always celebrate with dithyrambs, but whenever they poured libations, they did so, amid wine and drunkenness, by celebrating Dionysus with song and dance ( $\mu \varepsilon \dot{\varepsilon} \pi \mathrm{ov} \tau \varepsilon \varsigma)$, while they celebrated Apollo quietly and in good order. Archilochus at any rate says: I know how 
how to lead the beautiful song of Lord Dionysus, the dithyramb, when my mind is thunderstruck by wine."). This fragment is usually interpreted as a drunken revelry in celebration of Dionysus, or as a primitive form of dithyramb, which was later improved and became a widely popular lyric genre. Instead of making quick conclusions about the early dithyramb, I suggest that we look at the fragment more closely. These two verses give us two terms related to lyric poetry - especially to choral

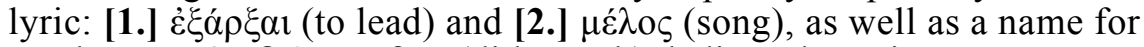
a cult song [3.] $\delta 1 \theta u ́ \rho \alpha \mu \beta o v$ (dithyramb) dedicated to Dionysus.

[1.] The word $\dot{\varepsilon} \xi \dot{\alpha} \rho \boldsymbol{\xi} \alpha \boldsymbol{\iota}$ points to Aristotle's theory on the origins

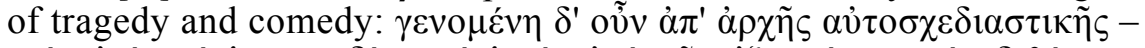

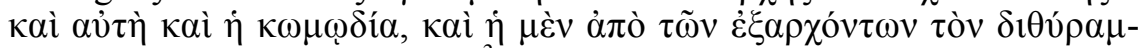
$\beta o v, \dot{\eta} \delta \grave{\varepsilon} \dot{\alpha} \pi$ ò $\tau \tilde{\omega} \nu \tau \grave{\alpha} \varphi \alpha \lambda \lambda \iota_{\alpha} \grave{\alpha}^{3}$ ("tragedy did come out of improvisational beginnings and comedy [too]: the first [i.e. tragedy] growing out of those who used to 'lead off the dithyramb, the second [i.e. comedy] out of those who led the phallic songs.") (trans. Whalley). This means that these choral songs were performed impromptu, without previous preparation. However, it is highly likely that the performers possessed some constant repertoire that was easily changeable and adaptable to various occasions. The verb غ̇ $\xi \alpha \dot{\alpha} \rho \chi \omega$, though, doesn't simply mean to begin, to make a beginning, to be first, as does the primary verb ö $\rho \chi \omega$, but to lead while being positioned outside (the group), to initiate, because the etymology of the preposition $\dot{\varepsilon} \xi$ denotes something that comes from the inside ${ }^{4}$. Accordingly, in dithyrambic performances there was a leadersinger and dancer ( $\dot{\varepsilon} \xi \alpha \dot{\alpha} \rho \omega \nu$, or $\ddot{\varepsilon} \xi \alpha \rho \chi 0 \varsigma)$, who stood outside the group and initiated the singing and dancing. "The dithyramb which was mentioned by this poet [sc. Archilochus] was a song that was initiated by a single voice and was followed by a refrain sung by the chorus." "The

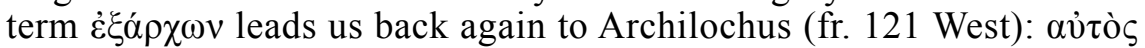

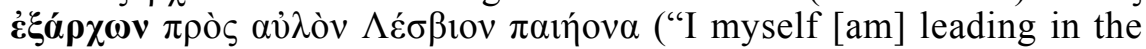
Lesbian paean to the aulos' accompaniment.") This $\dot{\varepsilon} \xi \alpha \dot{\alpha} \rho \chi \omega v$-figure was not appropriate to dithyrambs and phallic songs only, but rather it was a general term for the leader of cultic choruses that included processions and performance. ${ }^{6}$ The $\dot{\varepsilon} \xi \dot{\alpha} \rho \chi \omega v$-figure could be male or female, depending on the gender of the chorus, but he/she was not part of the chorus

to lead the beautiful song of Lord Dionysus, the dithyramb, when my mind is thunderstruck by wine."

* All translations are the author's unless otherwise indicated.

${ }^{3}$ Aristoteles Poet. 1449a10-11.

${ }^{4}$ Chantrain, $1968-1977$, p. 352 , compares $\dot{\varepsilon} \xi$ with the preposition $\dot{\alpha} \pi$ ó, which is translated similarly: from, by, of, but has the meaning venant de ("to come from"), as opposed to $\dot{\varepsilon} \xi$ which means de l'interieur de ("to originate", or "to emerge" from something, as part of something else).

${ }_{5}^{5}$ „Дитирамбот за кој говори овој поет е песна која ја започнува еден глас, а ја придружува хор кој возвраќа со рефрен.“ (Томовска, 2003: 51)

6 The first time the exarchon-figure was mentioned was in Homer (Il. 18.606). It is interesting that Homer presented two such procession-leaders who were positioned

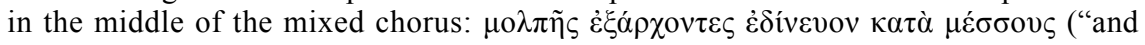


as is the коричаĩo (chorus-leader). ${ }^{7}$ Eric Csapo, by examining the iconography of these choruses in art, identifies an $\check{\varepsilon} \xi \alpha \rho \chi 0 \varsigma$-figure, by employing the following criteria:

1) "that the figures appear at the head of a procession;

2) that the figures be distinguished by appearance in some way from the other members of the chorus;

3 ) that the figures face the opposite direction of the movement of the chorus (i.e. they face the chorus);

4) that the figures gesture with their hands in ways which suggest communication with the chorus."

Csapo observes (2006/07: 64), that "the exarchos and the oral improvisatory performance he represents remained vigorous in public festivals to the very end of the $6^{\text {th }}$ century." The last of the exarchoi on potery belong to the realm of esoteric cult. Because his role emerged from processional choruses, it was only natural that when the dithyramb became part of the Athenian festival Great Dionysia, $\check{\varepsilon} \xi \alpha \rho \chi \varsigma$ was rep-

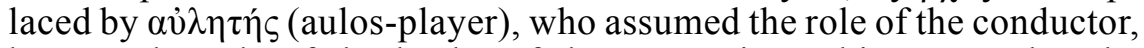
but not the role of the leader of the procession. This means that the dithyramb had already developed from a processional song (which accompanies the god) to a stationary song (stasimon) with circular chorus. ${ }^{9}$ However, the exarchoi as part of the festival culture were attested in inscriptions at Cyrene in the Hellenistic period. ${ }^{10}$ This proves that their function as chorus-conductors was not abandoned, i.e. they were not relics from the past.

The exarchos-figure sang outside the chorus - not with the chorus, but towards the chorus in the form of an amoebaeon. This model is confirmed in Bacchylides 18 which is a dithyramb song. Edmonds ${ }^{11}$ presupposes that "this Amoebeic element, which has its parallel in Sappho's Adonis-Songs and Epithalamies, was probably a very ancient feature of the Dithyramb". The question-answer form continued in tragedy and it was the only way of presenting the action in early tragedy (at the end of the $6^{\text {th }}$ and the beginning of the $5^{\text {th }}$ century BC) as well as in Aeschylus' early tragedies that have been preserved (Persians, Seven against Thebes, Suppliants). However, the amoebeic element is not detected in Pindar's dithyrambs, which are preserved in a fragmentary state. Pindaric chorus represents one voice only, the voice of the poet,

two tumblers whirled up and down through the midst of them as leaders in the dance" trans. Murray), who were also identified as $\kappa \nu \beta 1 \sigma \tau \eta \tau \tilde{\eta} \rho \varepsilon$, i.e. dancers with special (acrobatic) techniques.

${ }^{7}$ The chorus-leader at same time is part of the chorus, because he/she sings and dances with the other members, obviously assuming the leading role.

${ }^{8}$ Csapo, 2006/07, p. 60.

${ }^{9}$ On circular choruses see more D'Angour, 1997.

${ }^{10}$ See Paola Ceccarelli and Silvia Milanezi "Dithyramb, Tragedy - and Cyrene" in Wilson (ed.) 2007, pp.185-214.

${ }^{11}$ Edmonds, 1927, p. 667. 
because it doesn't assume a role. Pindaric dithyramb is not an example of a mimetic dithyramb.

[2.] The word $\boldsymbol{\mu} \dot{\varepsilon} \boldsymbol{\lambda} \boldsymbol{o} \varsigma$, usually translated as song, was used by the early lyric poets to denote their compositions, not simply songs ( $\grave{\omega} \delta \alpha i)$. In a dialogue about the lyric genres, Plato gives the following definition of the term melos, referring to what we identify as ancient lyric poetry:

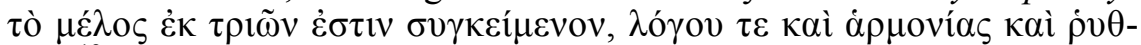
$\mu \mathrm{ov} .{ }^{12}$ ("Melody is composed of three things - speech, harmonic mode, and rhythm.") (trans. Bloom). Logos in this context would be the speech contents of the material sung in a musical harmony ( $\dot{\alpha} \rho \mu$ ovía), which is articulated through a musical instrument; the rhythm, on the other hand, is "the name for order in movement [...], and for order in voice, the mixture of sharp and deep, the name is 'harmony'; the two things together are called 'a chorus'." ${ }^{\prime 13}$ (trans. Pangle). Namely, the melos was not simply a song, but a musical composition, which was necessarily composed of the three already mentioned elements functioning as its parts. Even the performance of the chorus can serve as a proof of the melos structure, because it was not uniform as with the epic, elegy and iamb, but an elaborate performance of a trained group. Every part of the melos could be independent, though in that case speech would not be speech of a song, but something that was not discernable from everyday speech,

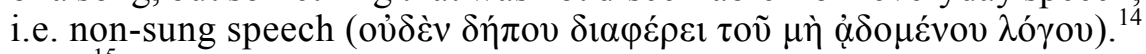

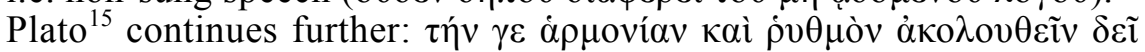
$\tau \tilde{\omega} \lambda$ ó $\gamma \omega$. ("The harmonic mode and the rhythm must follow the speech.") (trans. Bloom). This means that speech had the prime position in this combination, but it was not isolated.

Considering the composite nature of the word melos, ${ }^{16}$ it should be clear that when Archilochus said that he was singing dithyrambic melos to Dionysus, he did not mean that he had just started a simple song, but a complete musical composition, assuming the role of the leader of a cultic procession; the song in this particular procession could be improvised or not. The process of creating $\mu \varepsilon \dot{\lambda} \lambda \sigma \varsigma$ was called $\mu \varepsilon \lambda o \pi o l-$ $i \alpha$ (melody-making, melic composition, composing a melos), which, according to Aristotle, was the (internal, vertical or qualitative) part ( $\mu$ ó-

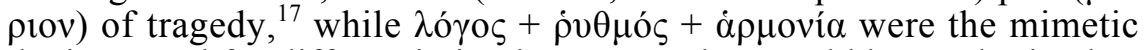
devices used for differentiation by matter; they could be used mixed or

12 Plato, Rep. 398d.

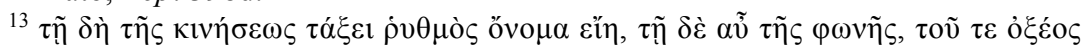

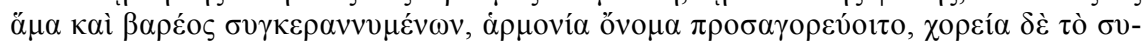

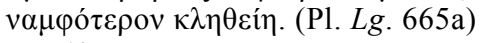

14 Plato, Rep. 398d.

15 loc. cit.

${ }^{16}$ In Homer $\mu \dot{\lambda} \lambda o \varsigma$ still denotes "member".

17 The music composition together with the plot (or structure of the events), the characters, the thought, the diction, and the visual element were called the "vertical" parts of tragedy. 
separately according to the (lyric) genre. ${ }^{18}$ Two things together make the music: the melody-making and the rhythms. ${ }^{19}$ Accordingly, "the melic composition $(\mu \varepsilon \lambda \mathrm{o} \pi \mathrm{oti} \alpha)$ together with rhythmic composition ( $\dot{\rho} v \theta-$ $\mu$ o $\pi$ otí $\alpha$ ) is the process of selecting and applying the various components of melos and rhythm to create a complete composition."20

From the later authors of the antiquity, who refer to Archilochus, we learn that the dithyramb had musical accompaniment that was not

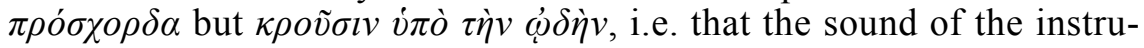
ment was no longer unified with the voice of the singer $(\pi \rho o ́ \sigma \chi o \rho \delta \alpha)$,

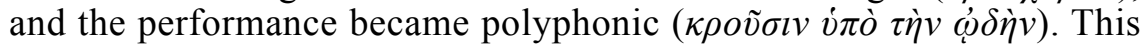
confirms the view that Archilochus' dithyramb was not a simple drunken revelry.

[3.] The third important thing in the Archilochus fragment is that the dithyramb is identified as a song dedicated to Dionysus and related to ecstasy, because he announces that his "mind is thunderstruck by wine". Of course, he doesn't refer to plain drinking and drunkedness, but to a part of a ritual, in which the poet becomes the enthusiastic leader of the Dionysiac hymn. Mendelsohn ${ }^{21}$ establishes a connection between the word $\sigma 0 \gamma \kappa \varepsilon \rho \alpha v v o ́ \omega$ ("to strike with or as with a thunderbolt, to shiver in pieces") and the Dionisiac cult language; therefore in Archilo-

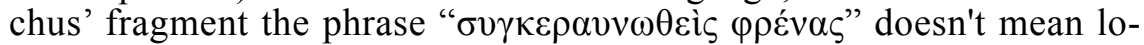
sing the mind from drinking, but implies deeper connection with Dionysus and his birth, provoked by Zeus' thunder. The connection between Dionysus and dithyramb is affirmed in Plato, who says that it is a kind

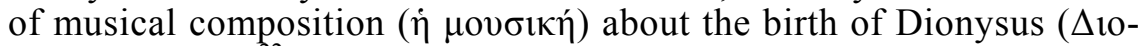

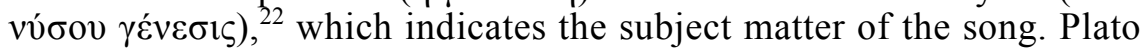
refers to the earlier forms of dithyramb, which weren't performed in his lifetime. Earlier in Pindar ${ }^{23}$, Dionysus was related to the dithyramb as well.

The word $\boldsymbol{\delta} \boldsymbol{\imath} \boldsymbol{\theta} \boldsymbol{v} \boldsymbol{\rho} \boldsymbol{\alpha} \boldsymbol{\mu} \boldsymbol{\beta} \boldsymbol{\rho} \varsigma$ ("dithyramb") has obscure etymology, which served as a basis for forming of several theories as early as the antiquity. More extensive interpretation is given by Proclus in Chrestomathia. ${ }^{24}$ According to him, the dithyramb derives its name from the name of Dionysus: either because he was born in a cave with two entrances near Nysa, or because he was found when Zeus's garments were

${ }^{18}$ See Aristoteles Poet. $1447 \mathrm{a} 22$.

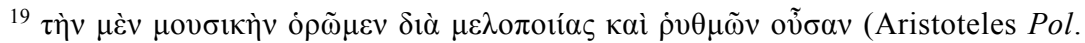
1341 b24) "We can certainly see that music consists of melody making and rhythms".

${ }^{20}$ Mathiesen 1999, p. 26.

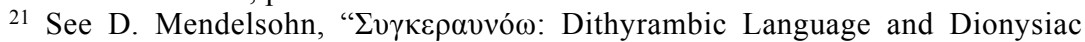
Cult". The Classical Journal 87, 1992, pp. 105-24.

${ }^{22}$ Plato, $L g .700$ a-b.

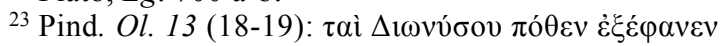

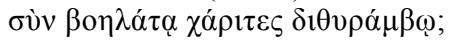

"Whence did the graces of Dionysus first come to light, with the ox-driving dithyramb?" (trans. Svarlien)

${ }^{24}$ Proclus apud Photium Bibl. 320a25-33; 320b12-16, 21-23. 
loosened, or because he was born twice - once from Semele, and the second time from Zeus's thigh. Proclus' etymologies are based on the following perceptions: the first one is clearly derived from the prefix $\delta$ - (two-) and $\theta v \dot{\rho} \alpha$ (door), which are the first three syllables of the word $\delta 1 \theta v \rho \alpha \mu \beta \beta_{\zeta}$; the second etymology is more obscure, and probably derives from the stem $\delta$ - (the same found in Zev́s, gen. form $\Delta \mathrm{t}-\mathrm{o} \varsigma$; from $\lambda v \theta-\left(\mathrm{cf} . \dot{\varepsilon} \lambda \varepsilon v \dot{\theta} \theta \varepsilon \rho \varsigma_{\varsigma}=\right.$ liberated); and $\rho \alpha \mu$ - (garment; cf. $\dot{\rho} \alpha \mu \mu \alpha=$ something sewed, $\dot{\rho} \alpha \dot{\pi} \tau \omega=$ sewing; but the stem of these words is $\dot{\rho} \alpha \varphi-$, so this etymology is incorrect). "The third is not based on the combination of the words that appear in the etymology but rather on the two $(\delta 1)$ triumphs $(\theta \rho i \alpha \mu \beta o \varsigma)$ of Dionysus's legendary double birth from the union of Zeus and Semele." 25 These ancient etymologies are refuted by the quantity of the vocal $t$ : in $\delta 1 \theta v \rho \alpha \mu \beta$ o $l$ - is long, in $\delta i \theta v \rho o \varsigma l$ - is short.

Kajetan Gantar ${ }^{26}$ gives a survey of the recent modern etymological theories and divides them in two groups: 1) Scholars who see in the dithyramb a word with non-Greek, Aegean or Phrygian origin, pointing out that the the suffix - mbos, is evidently non-Greek; 2) Scholars who try to link this word with Greek linguistic elements. Gantar's example for the second group of scholars is Milan Grošelj, who splits the word dithyramb in: $\delta 1-$ (the same stem as in the noun $\delta$ ív $=$ whirlpool, eddy, circular motion, rotation, hence dancing); the stem $-\theta v \rho-$, and; the suffix $-\mu \beta$ os, which according to Grošelj has Greek origins same as the word $i \alpha \mu \beta o \varsigma$ (iamb). According to this group of scholars, the word dithyramb primarily meant "dancing whirpool", i.e. rhythmical cultic dance in honour of the god Dionysus. So, the dance element had primacy over the music and song-speech; only later did these elements gain equal participation in the dithyrambic processions.

The suffix $-\mu \beta$ os, to which Grošelj and other scholars refer, is indicative of the nature of this cultic song. It is found in other songs associated with the cult of Dionysus or Demeter (both are vegetative

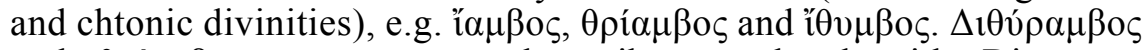
and $\theta \rho i \alpha \mu \beta o \varsigma$ are songs and attributes related with Dionysus. $\Delta \mathrm{t} \theta \dot{v} \rho \alpha \mu \beta \mathrm{o} \varsigma$ as a cult name of this god is attested in Euripides (Bacchae 526), and Pratinas ${ }^{27}$ (fr. 3.16), though its semantic function is different from that of the dithyramb as used by Archilochus.

\subsection{The Early Poets}

The first poet known to have composed a particular dithyramb is the lyric poet Ibycus of Rhegium, whose floruit was in middle of the $6^{\text {th }}$ century BC. This information is known from the scholion on Euripides' Andromache, but except for this, no further evidence is available. The

\footnotetext{
${ }^{25}$ Mathiesen, 1999, p. 75.

${ }^{26}$ Gantar, 1980.

${ }^{27} \theta \rho 1 \alpha \mu \beta о \delta ı \theta \dot{\rho} \rho \alpha \mu \beta \varepsilon, \kappa 1 \sigma \sigma o ́ \chi \alpha 1 \tau^{\prime}$ ö $v \alpha \xi$

(“Thriambos-dithyrambos, ivy-crowned Lord!”)
} 
scholion says that Ibycus already used the story about Menelaus meeting Helen in Aphrodite's temple, and that he used it in a similar manner in a dithyramb song. This story implies an amoebeic structure, judging

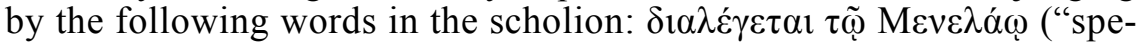
aks to Menelaus"). Nevertheless, Ibycus was never mentioned as dithyrambic poet; the tradition from the antiquity referred to two other poets as the creators of the formal dithyramb: Arion of Lesbos and Lasus of Hermione.

The data concerning these two poets and the formal beginnings of dithyrambic poetry differs in many respects and is not very reliable. Herodotus $^{28}$ delivers the first story, saying that Arion (fl. $600 \mathrm{BC}$ ), who came from Methymna on Lesbos was the finest singer accompanied by a lyre and the first poet to bring the formal dithyramb to Corinth, after he had made some formal improvements to the chorus:

"This Arion was a lyre-player ( $\kappa \imath \theta \alpha \rho \omega \delta$ óv) second to none in that age; he was the first man whom we know to compose and name the dithyramb which he afterwards taught at Corinth [during the reign of Periander]." (trans. Godley)

Herodotus also tells us about an adventure concerning Arion's singing profession, ${ }^{29}$ a story corroborated in the late Byzantine lexicon Suda. According to Herodotus, Arion was brought to Taenarus by a dolphin, having been kidnapped by pirates on his way back to Corinth from southern Italy. He was saved because of his marvelous singing.

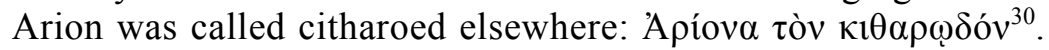
He was never referred to as an author of dithyrambic compositions by other authors from the antiquity except for Proclus and Suda. Proclus, who was quoted by the late Byzantine author Photius, ${ }^{31}$ says the following: "According to Pindar the dithyramb was invented at Corinth, and we are told by Aristocles that the originator of this song was Arion, the

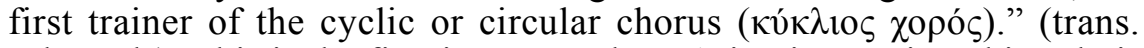
Edmonds). This is the first instance where Arion is mentioned in relation with circular choruses. Archilochus, on the other hand, never mentioned the circular chorus, nor we have any information, dated earlier than Aristophanes, that linked dithyrambs and circular choruses. We should regard this as an anachronism, which is not unusual, because, at the end of the fifth century BC, the dithyramb was already a circular chorus.

We find more information about Arion in Suda:

"Arion: Of Methymna, lyric poet, son of Cycleus, flourished in the 38th Olympiad (BC 628-625). According to some authorities he was

${ }^{28}$ Herodotus, Hist. I 23.

${ }^{29}$ Herodotus, Hist. I 24.

${ }^{30}$ Plutarch. Moralia, 18.161a.

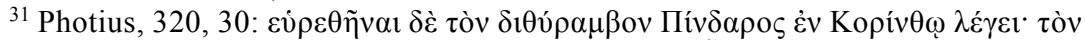

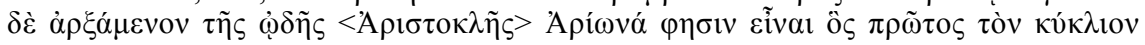

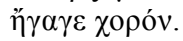


a pupil of Alcman. He composed songs, namely two Books of Preludes to Epic poems. He is also said to have been the inventor of the tragic style, and to have been the first to assemble a chorus ( $\chi$ opòv $\sigma \tau \tilde{\eta} \sigma \alpha \mathrm{l}$ ), to sing a dithyramb, to give that name to the song of the chorus, and to introduce Satyrs speaking in metre." (trans. Edmonds)

What differentiates Archilochus' dithyramb from Arion's? There isn't a precise answer to this question. Suda is a very late text and we cannot rely unreservedly on its information. The circular chorus, on the other hand, shouldn't be related to the dithyramb before the Great Dionysia Festival at Athens, which is relatively late with respect to these poets. What we can assume is that Arion was a famous lyric poet, who gave the shape and subject matter to the cultic Dionysian hymns - the dithyrambs at Corinth, which in Archilochus had more spontaneous shape and improvised text based on a familiar subject-matter. What Arion did perform at the beginning at the $6^{\text {th }}$ century $\mathrm{BC}$ was primitive compared to the same lyric genre at the end of the same century in Athens, when Great Dionysia became the most popular freshly established or reestablished festival in honour of Dionysus. Tradition says that Lasus of Hermione was the first who produced dithyrambs in Athens, and this happened when Thespis introduced tragic choruses at the Great Dionysia festival $(536 \mathrm{BC})$, or a little earlier - in the middle of the sixth century BC. Very little information is available on Lasus: he wrote asigmatic

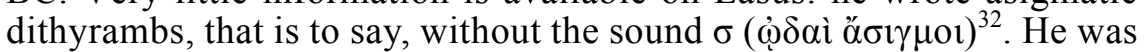
a music teacher to Pindar. His innovation was in the choruses, which in this period were composed of fifty chorus-members, whose performing place was the orchestra. According to Pindar's scholion ${ }^{33}$, he was Arion's follower, and according to Pseudo-Plutarch, ${ }^{34}$ Lasus made some innovations in the technique of aulos-playing, which were considered revolutionary at the time: "Lasus of Hermione, by adapting the rhythms to the dithyrambic movement, and by using more notes obtained by

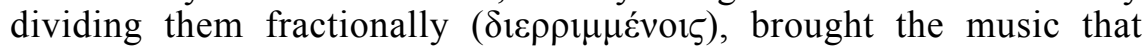
existed before his time into an altered state.” (trans. Levin). If Arion was credited with innovations in the chorus gathering and the dance, then Lasus is responsible for the musical improvement of this cultic song.

\section{Generic Identity}

\subsection{Performance and Performers}

\section{Circular or Processional Chorus}

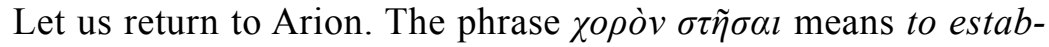
lish chorus, but it could be interpreted as Arion being the first to make

${ }^{32}$ Athenaeus, Deipn. 2,2, 47.

${ }^{33}$ Schol. Pind. Ol.13.266.

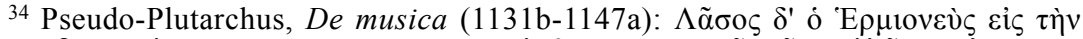

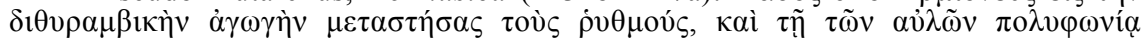

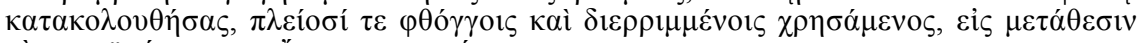

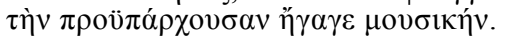


the chorus stand in the orchestra and sing stasimon ${ }^{35}$ - a song from the orchestra, a standing song, as opposed to a processional song $\left(\pi \mathrm{o} \mu \pi \eta^{36}\right)$. This means that the chorus did not simply stand in the orchestra and sing, but that the dithyrambic chorus stopped functioning as a processional chorus.

The theory that the dithyramb, from a processional and straightline song and dance, became circular chorus-song, sung and danced around an altar, was instigated by Pindar's fr. 70b, which itself is a dithyramb. He announces, in the first lines, a programmatic change in this kind of lyric songs:

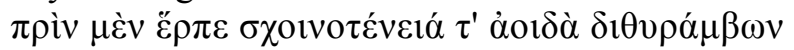

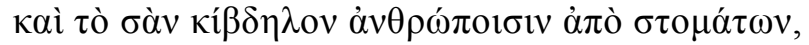

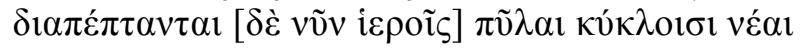

"In the past the song of dithyrambs came forth stretched, straight like a measuring-line, / and the [letter san $=/ \mathrm{s} /]$ came falsely from the mouths of men, / but now new gates have been opened for the holy circular [choruses]."

Pindar clearly contrasts the old and the new form of dithyramb,

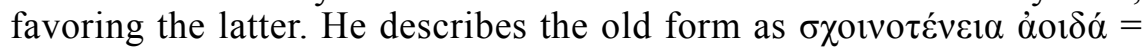

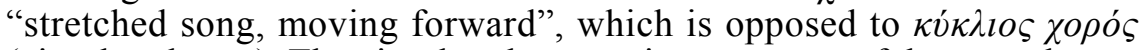
(circular chorus). The circular chorus points to a type of dance and song performed by a chorus, which sang and danced in a circle, presumably around some focal point. This kind of dance, according to the existing iconography, had a long history in Greece that preceded the dithyramb. In his study about Bacchylides, David Fearn argues that the misinterpretation of the dithyrambic genre originates from the equation of this Dionysiac genre with the circular choruses ${ }^{37}$. The second is a generic term for the type of dance which was extremely popular in Athens, while the dithyramb was a cultic hymn, which the chorus also performed following the $\kappa v ́ \kappa \lambda$ io $\chi 0 \rho o ́ \varsigma$ model. Fearn ${ }^{38}$ cites Athenaeus in support of his hypothesis: "There was a different type of music among the Greeks, but the Athenians used to prefer Dionysiac khoroi and circular ones." ${ }^{39}$ Fearn also refers to Birds $(377-1409)$ by Aristophanes, where the producers of dithyrambic and circular choruses were also mentioned. Accordingly, the dithyrambic choruses and the circular choruses were not the same, but were very closely related in Athens.

\section{The Festival and the Chorus}

There is no doubt that a dithyramb is a song in honour of Dionysus, though there is evidence that this song was performed on many occasions

\footnotetext{
${ }^{35}$ It is the same stem as in $i \sigma \tau \eta \mu \mathrm{r}$ "make to stand".

${ }^{36}$ It is the same stem as in $\pi \dot{\varepsilon} \mu \pi \omega$ "send".

${ }^{37}$ Fearn, 2007, p. 164.

38 2007, p. 165.

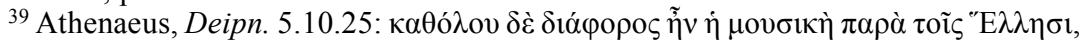

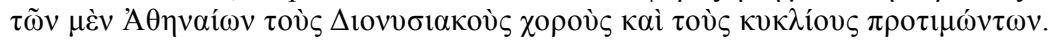


in Athens ${ }^{40}$. "In Classical times the most important non-Dionysiac festivals, of which circular choruses (principally dithyramb) formed a part, were those of Apollo." ${ }^{41}$ However, the dithyramb achieved its popularity primarily at the Athenian festival of Great Dionysia, organized in honour of Dionysus. This festival is the major source of information concerning the performances and the performers. The festival was (re)established in the second half of the $6^{\text {th }}$ century BC, during the reign of the sons of Pisistratus. It was an important part of their cultural program, which was not very different than those of the other tyrants. It was customary in the Greek oecoumene to celebrate Dionysia, i.e. festivals in honour of Dionysus, during the month of Anthesterion (February/March). Athenian Great Dionysia, however, was celebrated in the month of Elaphebolion (March/April). All things point to a possible dislocation of the religious purpose of the festival. Csapo points to the fact that: "c. $508 \mathrm{BC}$, the Athenian Dionysia differed from other musical festivals in frequency, in scale, and in the variety of economic interests directly involved in its operations. We know of no other annual musical festival before the Dionysia. Its venue, the Theater of Dionysus, was also larger than any other, holding in the fifth century even on more restrictive current estimates, probably close to 7,000 spectators in the seating area (theatron) and possibly many more on the hillside above it. Financing the festival combined money from the state, from donors, from private investors, and, for the very first time in the history of Greek religious festivals, there were admission charges." ${ }^{42}$ Let us add that for these very reasons the festival was not held in the month of Anthesterion, but in a period when the sea was navigable and strangers could visit the festival as well, i.e. in the month of Elaphebolion. The Great Dionysia festival was not considered Panhellenic, but still, it surpassed the popularity of the Panhellenic festivals, because of the innovation that was introduced in the festival culture. This is the reason why genres that were widely popular among the Greeks, but were not part of the mainstream before, were performed during the Great Dionysia; or alternatively, they became even more popular and achieved their formal shape because of the festival(s), and thus became mainstream. Two important genres were performed at the Great Dionysia: drama (tragedy, satyr-play and comedy) and dithyramb. Both were in honour of Dionysus. On the first day of the festival 10 dithyrambs were performed. Each chorus was a representative of its own tribe and consisted of fifty men who sang and danced in a circle accompanied by an aulos-player who stood in the middle of the circle. As opposed to the dramatic genres, it was not individuals, but groups that were competing with their dithyramb performances, as representatives of certain tribes in Athens.

\footnotetext{
${ }^{40}$ Anthesteria (in honor of Dionysus; February/March), Thargelia (in honour of Apollo and Artemis; May/June), Hephaestaea (in honour of Hephaestus; unknown date) and the Prometeia (in honour of Prometheus; unknown date).

${ }^{41}$ Ceccarelli, Milanezi in Wilson 2007, p. 198.

${ }^{42}$ Csapo, 2010, p. 83.
} 
Therefore, the victory of the chorus meant a victory for the tribe from which the chorus-members originated.

The documented performance history does not report female dithyrambic choruses. According to Calame, there is a possibility that, in the archaic period, women too performed dithyrambs; his argument is based on an epigram devoted to the choral lyric poet Simonides, as well as on Plutarch, who claimed that women in Elis performed a ritual song dedicated to Dionysus that might be a dithyramb:

"The ritual song that the women of Elis, according to Plutarch,

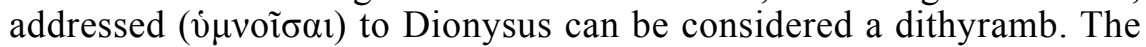
presence in this song of a refrain suggests that this dithyramb was sung by a single woman and that the chorus of her companions took up the refrain." 43

Nevertheless, in their celebration Dionysus still has the role of a hero, not of a god as in Archilochus' dithyramb. And from the performances at the Great Dionysia in Athens we know that the dithyramb was a song performed by a chorus of men or boys, who were fifty in number. The large number of choreuts, on the other hand, points to the term $\tau v \rho \beta \alpha \sigma i \alpha,{ }^{44}$ used to denote the nature of the dithyrambic choruses, stemming from $\tau \dot{v} \rho \beta \eta$ meaning disorder, confusion, tumult.

The appearence of the dithyrambic choreuts was pompous, appropriate to the dance and to the occasion; they wore neither masks nor costumes, as it was the case with the performances of tragedy and comedy, but festive robes and wreaths. This feature is evident from the iconography mostly; this is yet another indicator that dithyrambic performance was festive, same as the other lyric genres performed on public festivals. We should recall Alcman and his parthenia, in which the girls are referring to their festive robes and the festival. This particular festivity matches the text, as well as the occasion on which it was produced in the first place. But the iconography shows that the dithyrambic choreuts were not unified in costume; and indeed, they wore same outfits, but they differed in details, which might have served as an indicator of the different identity of the chorus-members, ${ }^{45}$ which implies possible solo-performances. Again, Alcman's girls are dressed and decorated in similar but different robes, which is evident from the text.

\section{Dithyrambic Music}

Dithyrambic music was very distinctive in comparison to other lyric genres. This notion is derived from the secondary evidence that emphasizes the Bacchic character of the music. But the question is:

${ }^{43}$ Calame, 1997, p. 79.

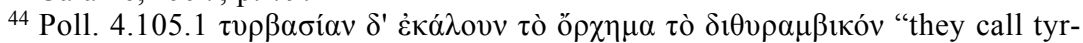

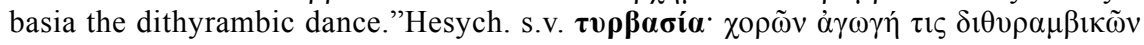

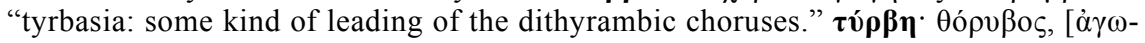

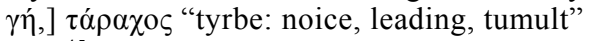

${ }^{45}$ Wellenbach (2015) examines this phenomenology. 
What is Bacchic music? Can words describe this phenomenon? When something was qualified as Bacchic, it was supposed to possess certain features that surpassed the dithyramb and were associated with the Dionysiac cult in general. With respect to music, this applies to song and dance performed in accompaniment of aulos, which is a wind instrument widely used in this type of songs and processions, or percussion instruments that effectuate ecstatic ambient and joyful feelings.

In his Politics, in the context of education of the youth, Aristotle explains which type of music is appropriate for educational purposes and depicts the Dionysiac music:

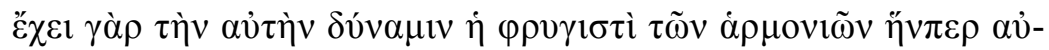

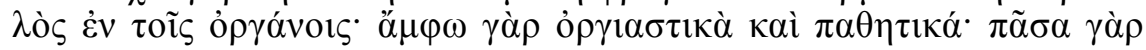

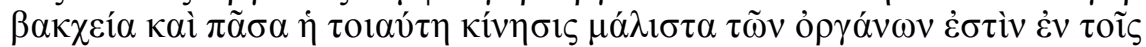

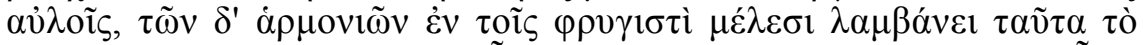

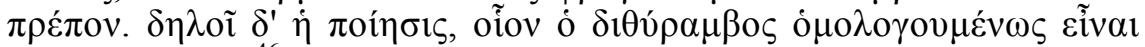

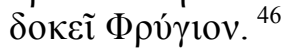

"The Phrygian musical scale (= harmony) has the same power among the musical scales that the aulos has among the musical instruments, since both are frenzied and emotional. For all Bacchic frenzy and all motions of that sort are more closely associated with the aulos than with any of the other instruments, whereas among the musical scales, the Phrygian music compositions are the ones that are suited to them. Poetry shows this clearly. For example, the dithyramb is generally held to be Phrygian."

From this description we learn that the dithyramb, at least in Aristotle's time, had Phrygian musical scale (= harmony), which was far

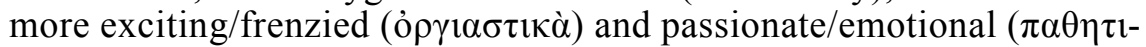
$\kappa \alpha ́$ ) than the Doric music scale used for composing paeans. The Phry-

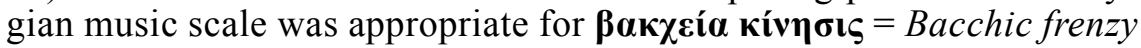
/ wild movement. But the term Bacchic and its derivatives were used as a general term for passionate acts, even in Plato's dialogues. This type of music was played on an appropriate musical instrument, the aulos, which sounds more passionate than the lyre or the deep sounding cithara. It was a processional instrument, used in paeans and in elegiac poetry as well, in order to achieve the special effect of stimulating certain feelings. Actually, aulos became the most popular instrument at the end of the $6^{\text {th }}$ and during the $5^{\text {th }}$ century $\mathrm{BC}$, and was used in dramatic performances.

So, the dilemmas about the generic type of lyric songs in general could have been solved if only we had had more information about the musical element. No doubt they sounded very differently when performed, and evidently they looked very differently judging by the dance moves and festive decoration.

\footnotetext{
${ }^{46}$ Aristoteles, Pol. 1342b 1-8.
} 


\subsection{The Text}

I have mentioned three names related to dithyrambic poetry: Ibycus, Arion and Lasus. Of these, only Lasus is related to Athens, which will be considered the birthplace of the formal non-cultic dithyramb. The second generation poets of dithyrambs, who are related to Athens as well, are the following: Simonides of Ceos (ca. 556-468 B.C), who mentions in one of his epigrams that he has won the first prize in the dithyrambic contests fifty six times, but none of his works has been preserved; ${ }^{47}$ Pindar of Thebes (ca. 522-446 BC), who wrote two books of dithyrambs, ${ }^{48}$ but only a few are preserved in an incomplete form; Bacchylides of Ceos (fl. 480-430 BC), whose six dithyrambs are preserved almost completely. The third and the last generation of dithyrambic poets included Philoxenus and Timotheus, who were considered innovators in the field of music. Unfortunately, only small fragments and some titles are preserved from their opus, but also a great bulk of secondary literature. In fact, the later definitions of dithyramb are largely based on the works of these poets, who were not considered in this discussion.

How can we be certain that the preserved texts by Pindar and Bacchylides are dithyrambs? The only thing that leads us to consider them dithyrambs is the classification of the Alexandrian philologists, customarily marked on the papyri. We discussed the generic markers concerning the performance and performers, with conclusion derived mainly from secondary sources. Now we need to find the generic markers that are related to the text, preferably on the basis of dithyrambic texts. In the Hellenistic period, the learned philologists made their generic classifications of poetry based on internal and external markers. They did not have the opportunity to see the performances of the archaic lyrics, since re-performances were rare, or were very different from the original. As we have seen, the dithyramb had had a Dionysiac context since the very beginnings in the archaic period; and yet, a major part of the songs that are preserved today as dithyrambs do not have subject matter that involves either Dionysus or Dionysus' birth. The dithyrambs by Bacchylides and Pindar show little or no connection to Dionysus. It is due to the changes that became visible during the period when dithyramb was formally performed. Since then, the dithyramb became a narrative and mimetic lyric genre, while at the end of the $5^{\text {th }}$ century $\mathrm{BC}$, dithyramb underwent another essential change under the influence of the so-called New Music. But should we take this feature as generic?

\section{Narrative and Mimetic Lyric Genre}

The narrative element was a predominant feature in many lyric genres. From the fragments remaining from the works by Pindar and

\footnotetext{
${ }^{47}$ It is known that he wrote dithyrambs entitled Europe and Memnon; he might as well had written a dithyramb on Danae, if the preserved fragment 543 belongs to a dithyramb and not to a threnos, as it is generally accepted.

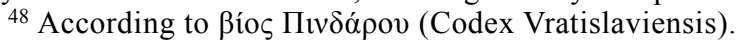


Bacchylides we can cite the following statements: 1) dithyramb is a narrative genre (Bacchylides) or 2) dithyramb is a lyric genre with narrative elements (Pindar). This ambiguity can be explained with comparison to tragedy. Here I will cite Swift's explanation:

"Tragedy's ability to incorporate other genres is enhanced by the fact that tragedy (like dithyrambos) is not as bound by its own performance function as a ritual chorus is. The tragic chorus's role as a chorus performing within the festival context of the Dionysia is blurred by the fact that it simultaneously claims a second identity as a different group in the fictional world of the play.",49

When the dithyramb ceased to be a processional song, it had the liberty to incorporate characteristics of other lyric genres, still retaining its Dionysiac context and spirit. Tragedy influenced dithyrambic poetry the most since they were performed at the same festival. This influence is evident in Bacchylides, in whose songs the narrative has a dominant role.

But according to ancient testimonies, dithyramb was indeed a narrative and mimetic genre. Let us cite Plato's notion that dithyrambic poetry is predominantly narrative and mimetic:

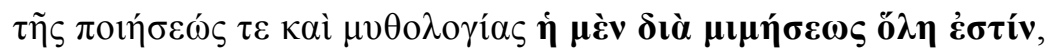

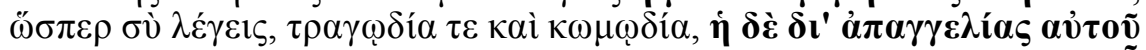

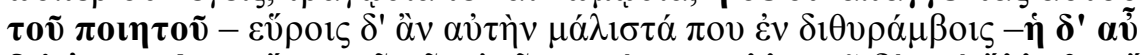

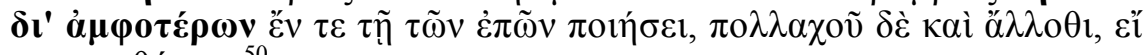

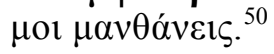

"there is one kind of poetry and tale-telling which works wholly through imitation, as you remarked, tragedy and comedy; and another which employs the recital ( $\left.\delta \imath^{\prime} \dot{\alpha} \pi \alpha \gamma \gamma \varepsilon \lambda i \alpha \varsigma\right)$ of the poet himself, best exemplified, I presume, in the dithyramb; and there is again that which employs both, in epic poetry and in many other places, if you apprehend me." (trans. Shorey)

In order to explain this passage from Plato as essentially vital for the systematization of poetry and the dithyramb, Peponi ${ }^{51}$ starts with the observation that, even though there are three kinds of poetic lexis: 1) $\dot{\eta}$

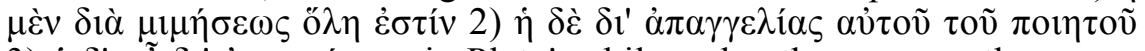

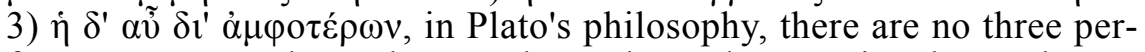
formance agents, but only two: rhapsodes and actors, i.e. those who are appropriate for the first (drama) and the last (epic) poetic lexis. The second poetic lexis, attributed to the dithyramb, is normally linked with the chorus as its performance agent. But, there is not in this case because the phrase $\delta t^{\prime} \dot{\alpha} \pi \alpha \gamma \gamma \varepsilon \lambda i \alpha \varsigma$ is not equal to $\dot{\alpha} \pi \lambda \tilde{\eta} \delta$ iń $\gamma \eta \sigma ı s$ (simple narration), especially if we take into consideration, that in Plato's time, the dithyramb became a mimetic lyric genre. Peponi argues that $\alpha \pi \alpha \gamma \gamma \varepsilon \lambda i \alpha$

\footnotetext{
${ }^{49}$ Swift, 2010, p. 26.

${ }^{50}$ Plato, R. 394b8-c5.

${ }^{51}$ See Peponi, 2013.
} 
and $\dot{\alpha} \pi \alpha \gamma \gamma \varepsilon \dot{\varepsilon} \lambda \lambda \varepsilon ı v$ throughout the entire Platonic corpus "denote oral transmission of a narrative and they are therefore used often in context involving performance." ${ }^{, 52}$ Therefore, we can conclude that the dithyramb is not exclusively a narrative genre, but a performance genre with a narrative element. "By performing the dithyrambic poem vocally and kinetically, the chorus is in fact turned into an active dramatic agent."

P.Oxy 2368, on the other hand, mentions two criteria for generic classification of the dithyramb: the presence of a refrain ( $\dot{\varepsilon} \pi \dot{i} \varphi \theta \varepsilon \gamma \mu \alpha$

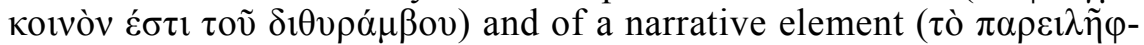
$\theta \alpha$ ). The commentator points out that Aristarchus qualified a specific poem titled Cassandra to be a dithyramb, whereas Callimachus classified it as a paean. The song is believed to belong to Bacchylides. Ian Rutherford says: "Two forms of dithyrambs are known, the Dionysiac and the narrative, and Aristarchus seems to have been thinking of the latter. Most $\pi \alpha i \tilde{\alpha} v \varepsilon \zeta$ are narrative too, so it would be surprising if Aristarchus presupposed that narratives had no place in the $\pi \alpha$ lóv." 54 The extended mythological narrative, which Aristarchus considered as one of the characteristics that defined the dithyrambic genre, was not exclusive to this genre only.

Considering the choice of stories, we cannot distinguish a pattern. Aristotle in his Poetics defines the dithyrambic poetry as mimetic, ${ }^{55}$ using the term $\delta \imath \theta v \rho \alpha \mu \beta о \pi о \imath \eta \tau \iota \kappa \eta$ which implies a special process, different from the art of making other lyric poetry. But in Problemmata he

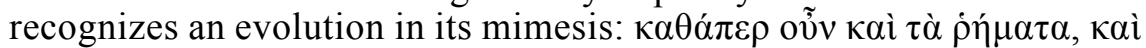

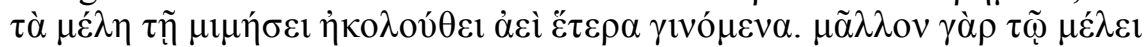

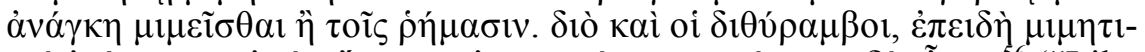

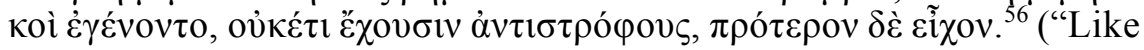
the words, therefore, the music conformed to the imitation, becoming constantly different; for it was more essential for the music to be imitative than the words. For this reason too dithyrambs, since they have become imitative, no longer have antistrophes, as they had formerly.") It is obvious that the dithyramb was not always a mimetic genre, as he announced in the Poetics. The chorus and the songs of the chorus, according to Aristotle, were less mimetic than the actor, and this was the

52 Peponi, 2013, p. 356.

${ }^{53}$ Id.

${ }^{54}$ Rutherford, 2001, p. 98.

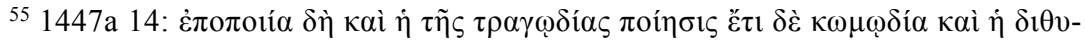

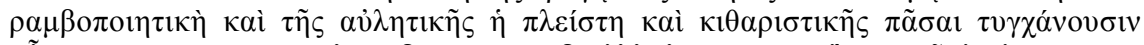

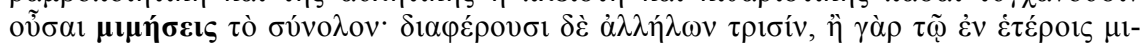

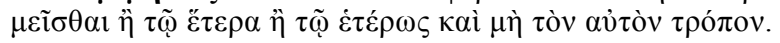

"Now epic-making and the making of tragedy, and comedy too, and the art of making dithyrambs, and most of the art of composing to the flute and lyre - all these happen to be, by and large, mimeseis. But these arts differ from one another in three respects: for they do their mimesis? (a) in different matter (in-what), (b) on different subjects (of-what), and (c) by different methods (how)." (trans. Whalley)

${ }^{56}$ Aristoteles, Probl. 918b, 19. 
reason why the chorus sang in an antistrophic form. Namely, the antistrophic structure developed in parallel with the lesser mimetic developments in the plot. In Aristotle's time dithyramb was not performed by civil choruses, but by professional choruses, so the antistrophic structure was not necessary. The dithyramb became mimetic and nonantistrophic. Still, we have seen clearly that some of Pindar's dithyrambs were only strophic, lacking the tripartite structure of Bacchylides dithyrambs.

In the later dithyramb as well as in the nomos, monodic (solo) performances prevailed, and the antistrophic structure was abandoned. This tendency was particularly noticeable in Euripides, in whose tragedies the lyric parts were often replaced with solo performances of professional actors.

According to G. Nagy, ${ }^{57}$ during the classical period in Athens, the solo performance of lyric poetry, both melic and non-melic, became highly professionalized, including the actors in drama. Melic poetry, on the other hand, was sung and danced by non-professional choruses. The chorus-members status changed at the end of the classical period and this was the chief reason for the formal changes in choral poetry.

It seems that the older dithyrambic songs were cultic hymns dedicated to Dionysus, in which the narrative did not have an essential role. The later dithyramb, the so-called literary dithyramb was focused more on the narrative element, which was exclusively taken from mythology. This difference is noticeable in the comparison between Pindar and Bacchylides, that is to say, the narrative element was not a hallmark of their dithyrambic poetry only, but of their other lyric poems as well. However, there is difference: Pindar was not much concerned with the narrative and relied on a highly informed audience throughout his entire oeuvre, while Bacchylides was famous for his story-telling, i.e., composing highly narrative lyric, which might be an influence from tragedy, or due to his adapting of his poems to the different occasions. Where was Dionysus in these songs? In Pindar the god was celebrated at the beginning, while the narrative line was free to introduce elements from another story. Dionysus was absent in Bacchylides, except in Ode 19 where the god was mentioned. The structure of the poems was usually triadic, but this was a common practice for the entire choral lyric at that time.

That the subject-matter doesn't have to be taken from the life of Dionysus, is clear from the Homeric hymn to Apollo, where the Deliades - a chorus of young girls on Delos, sing a song for Apollo, but not about Apollo. The god might be mentioned in the invocation, but the story afterwards, as the hymn says, is about heroes and people from the past. $^{58}$

\footnotetext{
${ }^{57}$ Nagy, 2007, pp. 20-21.

${ }^{58}$ Homeric hymn to Apollo, III, 146-164.
} 


\section{Language and Style}

The purpose of this section is not to offer an elaborate interpretation of dithyrambic language and style, but to establish some general points that could lead to further examinations. For this purpose we should now reiterate Aristotle's notion that tragedy evolved from those who used to lead dithyrambic choruses. ${ }^{59}$ When Aristotle connects tragedy to dithyramb on one hand, and tragedy to epic on the other, he doesn't establish a genetic relation, but rather a connection based on the object of their mimesis. The object of the mimesis very much influences the dithyrambic lexis, i.e. it is reflected in the language. The dithyramb, epic, and tragedy, all have "serious" objects of mimesis, which in Greek

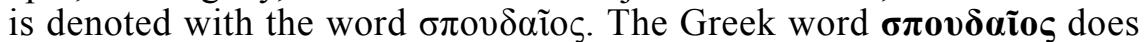
not simply mean serious, but also implies something that we must take into consideration and treat with respect. ${ }^{60}$ This means that the subject matter is not concerned with the ephemeral activities of the heroes, but with the problems that emerge from conflicts from the past and the present (in the case of tragedy), or simply with the heroic past (in the case of lyric poetry), which is sometimes brought as a paradigm for the present situation. These people are better than us ( $\beta \varepsilon \lambda \tau i ́$ ov $\alpha \varsigma)$, and they belong to another realm. ${ }^{61}$ When $\sigma \pi$ ov $\delta$ ĩo $\varsigma$ is taken as a qualifier for the type of poetry, it is valid for all its parts, including the characters and the language. So, we can qualify the dithyrambic language and style as serious in general. This is due to the performance context as well - after all, at the beginning, the dithyramb was a cultic hymn concerned with the birth of Dionysus.

We also possess other secondary evidence on the dithyrambic language, as well as modern theories and observations, which point to a highly stylized and elaborate language, manifested mostly through double epithets ${ }^{62}$ and abundance of epithets, as well as through teletic language and a choice of certain words and linguistic constructions. Let us now briefly examine Pindar's and Bacchylides dithyrambs - not to confirm or reject these evidence and observations, but to be sure that these phenomena are pertinent to dithyramb only.

In his scholarly paper on Pindaric dithyrambs, Hamilton ${ }^{63}$ offers an excellent investigation of dithyrambic features in Pindar by examining

\footnotetext{
${ }^{59}$ Aristoteles Poet. 1449a10-11.

${ }^{60}$ According to Aristotle's philosophy $\sigma \pi 0 v \delta \alpha i{ }^{\circ} \varsigma$ is a man that possesses part of some virtue ( $\dot{\alpha} \rho \varepsilon \tau \tilde{\eta} \varsigma)$. For example, the tragic heroes, as represented by the tragic poets, are virtuous and worthy; this is not in accordance with the modern moral view, but in accordance with the ancient concept of worthy and virtuous.

${ }^{61}$ Comedy, on the other hand, and the scoptic genres in general are not distanced from the trivial life, because they present the situations of the pav́novs, i.e. people that are worse than us.

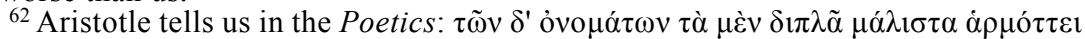

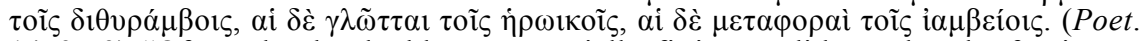
1459a 9) "Of words, the double are especially fitting to dithyrambs, the foreign to heroic hexameter, and metaphors to iambs." (trans. Whalley)

${ }^{63}$ Hamilton, 1990.
} 
the definition of dithyramb given by Pickard-Cambridge and R. Seaford. When Pindar's language is concerned, his examination rightly proves that Pindaric dithyrambs do not differ from his epinicians or paeans with regards to the epithets, or even with regards to his use of teletic language. The difference is based on the so-called Schema Pindaricum - a plural object with a singular word, i.e. "a collection of subjects which are mentally unified." Outside Pindar's dithyrambs, this feature is observed in tragedy only, and may be considered an influence from the dithyramb. Another distinguishing feature is the use of flowery epithets to describe spring flowers. We may add that this feature gives contemporaneity to the song, because the festivals were held mainly in spring, and is a reference to the occasion. This reference to the occasion, on the other hand, is a common feature of choral lyric in general.

I must emphasize that these are features typical of Pindaric dithyrambs; Bacchylides does not share the same language features. It is true that the language of Bacchylides is highly stylized and elaborate, but this is characteristic of his poetry in general. It is a fact that Bacchylides used an abundance of ornamental epithets, but they all have structural function in the whole; e.g. the epithets in Bacchylides 18 refer to the red color and masculine characteristic, because he describes the hero Theseus; Bacchylides 15 is a reminiscence of the Homeric diction, because its plot is taken from the Trojan cycle, an episode which is mentioned in $I l$. 3. described by Antenor. However, this kind of connectivity of the epithets with the main story is found in his epinicians as well.

The conclusion we can draw from Pindar's and Bacchylides' dithyrambs is that there is no difference between the style and language of Pindar's or Bacchylydes' dithyrambs and their other poems. Actually there is no clue as to what might the unambiguous difference be between the dithyrambic style and the other choral poetry in general. This conclusion is in contrast with Plato's and Aristotle remarks on dithyrambic language. Plato makes a very indicative remark on the style of the dithyramb, when he uses the adjective $\delta 1 \theta v \rho \alpha \mu \beta \tilde{\omega} \delta \varepsilon \varsigma^{64}{ }^{64}$ It is obviously used with a negative connotation - to describe a wild and boisterous language. ${ }^{65}$ But this view does not hugely differ from the view expressed in the Old comedy, where the dithyramb and dithyrambic poets are regularly ridiculed for their language and style. In his Poetics, ${ }^{66}$ Aristotle only confirms the view that dithyrambic language is stylized, especially when he refers to the compound epithets. He also expresses his negative opinion when he discusses the dithyrambic language in his Rhetorics ${ }^{67}$ by describing the poets as 'noisy': oṽ

I suggest that Plato's and Aristotle's notions, as well as the Old Comedy poets' attitude towards the dithyrambic style, refer to the later

\footnotetext{
${ }^{64}$ Plato, Cratylus 409c3.

${ }^{65}$ In Phaedrus (238d 3 and 241e2) Plato uses the word dithyramb yet again to explain the loss of self-control in speech and being seized by the nymphs.

66 1459a 9.

${ }^{67} 1406 \mathrm{~b} 2$.
} 
dithyramb, when the speech succumbed to music, and the words lost

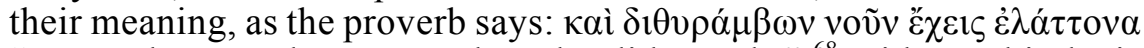
"you make even less sense than the dithyrambs". ${ }^{68}$ Dithyrambic lexis ( $\lambda \dot{\varepsilon} \xi 1 \zeta \delta \imath \theta v \rho \alpha \mu \beta ı \kappa \eta)$ has become a synonym for an empty talk without any profound meaning. Well, this is something we have not observed in Pindar and Bacchylides.

\section{Conclusion}

In the archaic and early classical period, lyric poetry was not qualified as much by its textual generic markers, as it was by the occasion and the performance. The early dithyramb was indeed melos, as were all the other lyric songs, which had specific ritual and religious features, on one hand, and formalistic, on the other hand.

This means that the dithyramb was a cultic hymn sung in honour of Dionysus, which had a complex textual structure and was accompanied by wild ecstatic dance and the musical instrument aulos. Its internal form was shaped as an amoebaeon at first, as confirmed by the title $\dot{\varepsilon} \xi \alpha \dot{\alpha} \rho \chi \omega \mathrm{V}$ and the position of this figure in relation to the chorus. The chorus was not by default circular, because it sang a processional song. Its subject matter was related to the birth of Dionysus. In the late archaic and early classical period, the dithyramb was no longer an improvised cult song, performed in a procession, but a highly artistic form of performance. The performance in a theater, indeed, prompted the changes concerning the music, text, language and dance of the dithyrambic choruses. The rise of the professional actors and choreuts also influenced some of the formal changes. The dithyramb became show-business - it was no longer a primitive ritual hymn.

Most of the data on dithyrambic performances was gathered from the Athenian festival Great Dionysia, which was a dramatic festival after all. This was the reason why dithyrambs appropriated so many formal features of tragedy; but the process was mutual. Hence, Bacchylides' dithyrambs did not suggest anything Bacchic about them, except for the violent myths, if we take into consideration that anything related to Dionysus, including his birth, was enveloped in violence. Pindar's dithyrambs were not very different from his epinician Odes, either in storytelling or language, except for the so-called schema Pindaricum and the depiction of spring flowers, which was a reference to the occasion. In comparison to other archaic choral lyric, dithyrambs showed no divergence: the artificial Doric dialect was used, which was a koine for choral lyric in general; epithets were borrowed from the epic and elegy; language was highly stylized; subject matter was serious; the appearance of the choreuts was festive, and; the performance was public. The only thing that differentiated these formal dithyrambs from other poetry

${ }^{68}$ This proverb is cited in the scholion of Aristophanes' Birds 1392 where dithyrambic language is widely parodied. 
with some certainty was the occasion and their music, which remained highly frantic and ecstatic even in Aristotle's time, and which unquestionably, linked this kind of song with Dionysus. Unfortunately, the music is the only element of the melos that cannot be restored with certainty. The purpose of this hymn was to celebrate Dionysus, as it would be appropriate for this god of ecstasy and frantic liberation.

\section{BIBLIOGRAPHY}

Aristoteles. Aristotle's Poetics. Translation by G. Whalley. McGill-Queen's University Press, 1997.

Athenaeus. Athenaeus: Deipnosophistarum libri xv. Edited by George Kaibel, Nabu Press, 2010 (repr.).

Calame, C. Choruses of Young Women in Ancient Greece: Their Morphology, Religious Role, and Social Function. Translated by Derek Collins and Jane Orion. Lanham: Rowman \& Littlefield, 1997.

Chantraine. Pierre. Dictionnaire Étymologique de la Langue Grecque. Histoire des mots I-IV, Paris, 1968-1977.

Csapo, E. Actors and Icons of the Ancient Theater. Chichester /Malden, MA: WileyBlackwell, 2010.

Csapo, E. "The Iconography of the 'EXARCHOS'", Mediterranean Archaeology. Vol. 19/20. Proceedings of the $25^{\text {th }}$ Anniversary Symposium of the Australian Archaeological Institute at Athens (Athens 10-12 October, 2005), 2006/07, pp. 55-65.

D' Angour, A. "How the Dithyramb Got Its Shape”, Classical Quarterly 47 (ii), 1997, pp. 331-351.

Edmonds, J.M. (ed. et transl.). Lyra Graeca vol. III. The Loeb Classical Library, London, 1927.

Fearn, D. Bacchylides: Politics, Performance, Poetic Tradition. Oxford University Press, 2007.

Gantar, K. Grške lirične oblike in metrični obrazci. Izdaja Slovenska Akademija znanosti in umetnosti, inštitut za slovensko literature in literaturne vede, 1980.

Hamilton, R. "The Pindaric Dithyramb". Harvard Studies in Classical Philology, Vol. 93, 1990, pp. 211-222

Herodotus. Herodotus, with an English translation by A. D. Godley. Cambridge. Harvard University Press, 1920.

Homer. The Iliad with an English Translation by A.T. Murray, Ph.D. in two volumes. Cambridge, MA., Harvard University Press; London, William Heinemann, Ltd., 1924.

Levin, F.R. Greek Reflections on the Nature of Music. Cambridge University Press, 2009.

Mathiesen. T.J. Apollo's Lyre: Greek Music and Music Theory in Antiquity and the Middle Ages. University of Nebraska Press, 1999.

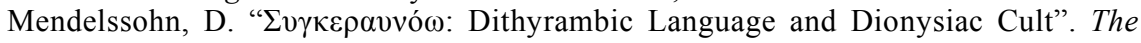
Classical Journal 87, 1992, pp. 105-24.

Nagy, G. "Lyric and Greek Myth", The Cambridge Companion to Greek Mythology. Ed. R. D. Woodard; Cambridge, 2007, pp. 19-51.

Pearcy Jr., Lee T.. "The Structure of Bacchylides' Dithyrambs". Quaderni Urbinati di Cultura Classica No. 22, 1976, pp. 91-98. 
Peponi, A.E. "Dithyramb in Greek Thought. The Problem of Choral Mimesis." In B. Kowalzig and P. Wilson (eds.), Dithyramb in Context. Oxford, 2013, pp. 35367.

Photius. Bibliotheca. Ed. P. Henry, 8 vols. Paris, 1959-77.

Pindar. Odes. Translation by Diane Arnson Svarlien in Perseus Project 1.0 (Yale University Press, 1991). < perseus.tufts.edu>

Plato. Plato: The Republic. Trans. by A. Bloom. (Second edition) New York: Basic Books, 1991.

Plato. The Laws of Plato. Trans. by T. Pangle. Chicago: The University of Chicago Press, 1980.

Plato. Plato in Twelve Volumes, Vols. 5 \& 6 translated by Paul Shorey. Cambridge, MA, Harvard University Press; London, William Heinemann Ltd, 1969.

Plutarch: Moralia. Edited by Gregorius N. Bernardakis, Leipzig: Teubner, 1892.

Rutherford, Ian. Pindar's Paeans: A Reading of the Fragments with a Survey of the Genre. Oxford University Press, 2001.

Swift, L.A. The Hidden Chorus: Echoes of Genre in Tragic Lyric. Oxford: Oxford University Press, 2010.

Томовска. В. Хорот и хорската лирика во грчката трагедија. Докторска дисертација одбранета на Универзитетот „Свети Кирил и Методиј“, Филозофски факултет - Скопје, 2003.

Wellenbach, Matthew C. "The Iconography of Dionysiac Choroi: Dithyramb, Tragedy, and the Basel Krater". Greek, Roman, and Byzantine Studies 55, 2015, pp. 72103.

West, M. L. Greek Lyric Poetry: The Poems and Fragments of the Greek Iambic Elegiac and Melic Poets (Excluding Pindar and Bacchylides) Down to 450 B.C. Oxford: Oxford University Press, 1999.

Wilson, P. (ed.). The Greek Theatre and Festivals: Documentaray Studies. Oxford University Press, 2007. 
